\title{
Sivan, Miryam. Make It Concrete. New York, NY: Cuidono Press, 2019.
}

\section{Reviewed by Merle Eisman Carrus, Hollis, NH, USA}

Listening to author Miyram Sivan talk about her newest release, the novel, Make It Concrete, the reader will develop a great appreciation for the story. Discussing this with a group would also be a wonderful way to really bring out all the nuances and deeper meaning of the plot, the title and connect readers to the characters. As a reader having long been consumed with an appreciation and interest in reading Holocaust fiction and memoirs, it is understandable to possibly find one's self feeling oppressed by these stories. It could eventually take a toll emotionally on an author or even a reader.

This is a novel with many layers to uncover. To read it on the surface is to miss the complexity involved. On the surface this is the story of a woman searching for happiness and meaning in her life. She is a divorced mother of three children living in Israel. Isabel Toledo is a descendant of Spanish Jewry. Even though she makes Aliyah, moving to Israel to marry her Israeli husband and raise her children there, she would not give up her name and connection to her past. Her father's family can trace its lineage back to the expulsion from Spain in 1492. Her mother, Suri, is a Polish Holocaust survivor who does not want to talk about her experience during the war.

Though Isabel asks her mother questions about her past, Suri always puts off the discussion, which has left Isabel frustrated and unfulfilled for years: "Isabel, sweetheart, life is beautiful, live it, and leave the dead alone. Suri took a delicate sip of wine. Her eyes looked up from the rim of her wine glass and met Isabel's. They told her flat out to mind her own business. The same message she had been receiving for the past thirty years." These pent up, confusing feelings have led her to leave the United States to live in Israel and work with Holocaust survivors, preserving their stories.

Now living with her youngest child, a seven-year-old son and her oldest daughter home from the army, she is struggling still with feeling like an outsider in Israel, never a true Sabra, always an American expat. Her middle daughter, serving in the Army now, tells her mother she is being transferred. When Isabel expresses her concern, the girl laughs. Isabel realizes she will never fit in: "Times like these reminded Isabel of how little she knew of this country. And its army. Even after all these years she got it wrong. Even after all these years she was an American outsider."

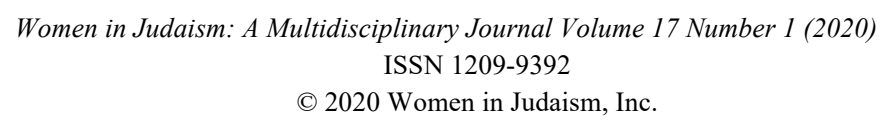


Isabel, as the ghostwriter of Holocaust survivors, tells other people's stories, one after the other for a demanding publisher in NY. She has written many books for him but this current book is becoming hard to finish. Isabel tells Emanuel, "Jaim Benjamin's book is just hard. Feels like iron chains are attached to the sentences." The survivor, Jaim Benjamin is a Greek Jew of Sephardic heritage like her father and it is disconcerting to her. This story seems to be more personal than the others, reminding her that her own mother has never told her story. It becomes harder and harder for Isabel to finish this manuscript. Taking on the burden of listening and sharing the Holocaust memoirs is getting more and more difficult. She is starting to see demons wherever she looks.

To try and find some peace, Isabel is involved in multiple relationships. There is the serious boyfriend, who is pushing to make the relationship more permanent. But Isabel cannot commit yet because she also has a young lover who she visits at construction sites and another man, on the side, she visits when in Prague. This is the one area of the book a reader could find a bit unrealistic. It could be hard to believe that a woman would get involved in so many sexual relationships at the same time without commitment. Isabel is looking for a way to avoid the demons in her head, but even with these affairs she cannot get rid of them.

Isabel loves to watch the concrete pours at construction sites: "Isabel purred with excitement. The masonry crew stepped forward to meet the mixers. After twenty minutes of prep, concrete began to flow from the drums. A metal pipe held high by a brontosaurus-like crane swallowed it and channeled it to a thick rubber hose. Isabel rocked with anticipation. The head of the crew seized the hose and used all the weight and force of his body to control the heavy surge of grey lava that rushed out of the bucking black hose."

Each of her relationships is similar to concrete, it starts off as a liquid and pours into a foundation that then becomes either strong and permanent or the cracks and defects appear and start to break it apart. There is even a sensuality to the descriptions of the concrete pours and how concrete is described in the book. Isabel is afraid to commit to Emanuel, who wants to marry her and offers permanence and stability. She is unsure about her young construction worker, because he is younger than she is and deserves to find true love and start his own family. She also picks up men 
while traveling for one-night stands. But the cracks are developing and the weakness of the concrete is starting to show.

The readers will enjoy Sivan's engaging prose and descriptions of Israeli locations as they follow the characters and encourage the ones they identify with to succeed. 